\title{
Synthesis, Molecular Docking Studies and Antibacterial Evaluation of Baylis-Hillman Adducts of Coumarin and Pyran Derivatives Using Ionic Liquid under Microwave Irradiation
}

\author{
A. SUNIL KUMAR, S. KANAKARAJU, \\ B. PRASANNA and G. V. P. CHANDRAMOULI*
}

Department of Chemistry, National Institute of Technology, Warangal-506 004, A.P., India gvpc2000@gmail.com

Received 20 October 2012 / Accepted 12 November 2012

\begin{abstract}
The Baylis-Hillman adducts 3(a-e) and 6(a-g) were prepared by the reaction of appropriate aldehydes with alkenes in presence of catalytic amount of urotropine with ionic liquids under microwave irradiation. Structures of the newly synthesized compounds were characterized by spectral studies. The antibacterial studies of Baylis-Hilmann compounds for analysis of the structural requirements for antibacterial activity using VLife MDS 3.5 has been carried out.
\end{abstract}

Keywords: Coumarin, Pyran, Baylis-Hillman, Ionic liquids, Microwave irradiation, Docking, Antibacterial activity

\section{Introduction}

Docking is a method of molecular modeling, which predicts the preferred orientation of one molecule to a second when bound to each other to form a stable complex. Molecular docking can be defined as an optimization problem, which would describe the "best-fit" orientation of a ligand that binds to a particular protein of interest and is used to predict the structure of the intermolecular complex formed between two or more molecules. The most interesting case is the protein ligand interaction, because of its applications in medicines. In modern drug designing, molecular docking is routinely used for understanding drug information about drug receptor interactions and is frequently used to predict the binding orientation of small molecule drug candidates to their protein targets in order to predict the affinity and activity of the small molecule.

Coumarin and its derivatives represent one of the most active classes of compound possessing a wide spectrum of biological activities such as, antibacterial, antifungal, antiinflammatory, anticoagulant, anti-HIV and antitumor activity ${ }^{1-4}$. In addition, these compounds are used as additives to food and cosmetics, optical whiteners, luminescence dyes, active media for lasers and solar collectors ${ }^{5,6}$.

Pyran derivatives exhibit a wide spectrum of pharmacological activities and biological activities such as fungicidal, insecticidal, acaricidal, antiviral, stimulant and anticonvulsant activity $^{7,8}$. 
Carbon-carbon bond forming reactions are usually essential tools for molecular architecture and also in total synthesis of organic compounds ${ }^{9}$. They have been the subject of vast investigations where upon now chemists are provided with several reactions like DielsAlder reaction, Wittig reaction, ring-closing metathesis, Ugi reaction, Passerini reaction, Heck reaction and recently the Morita-Baylis-Hillman reaction to create carbon-carbon bonds ${ }^{10}$. The commonly known Morita-Baylis-Hillman reaction (MBH) results in addition of an activated olefin (containing conjugated electron-withdrawing groups) onto an aldehyde, activated ketone or imine grouping at $\alpha$-position to afford some unique multifunctional alkenes ${ }^{11}$. From the above line of reasoning we directed our work towards synthesis of various coumarin and pyran derivatives of biological interest by following green chemical methods.

\section{Experimental}

Melting points were measured in open capillary on Buchi melting point B-540 apparatus and were uncorrected. IR spectra were recorded on Simadzu FTIR-8400 spectrometer using $\mathrm{KBr}$ pellets. ${ }^{1} \mathrm{H}$ NMR (300 MHz) spectra recorded in $\mathrm{CDCl}_{3}$ on a Bruker AVANCE 300 instrument with the TMS as an internal standard. All the chemical shifts values were recorded as $\delta$ ppm. Mass spectra (EI-MS) were taken on Perkin Elmer (SCIEX API-2000, ESI) at $12.5 \mathrm{eV}$. CHN analysis was carried out on Carlo Erba E A 1108 automatic analyzer. The progress of each reaction was monitored and purity of the compounds was checked by thin layer chromatography.

\section{Results and Discussion}

Urotropine is used as a reagent in ring-closure reaction, synthesis of triaza-, tetraaza-heterocyclic derivatives $^{12}$ and $\alpha$-methylation of aryl alkyl ketones ${ }^{13}$. Though, urotropine was reported as a base catalyst for Baylis-Hillman reaction ${ }^{14}$ its scope and generality were not tested for various aldehydes and activated olefins. Herein, we reported the synthesis of heterocyclics like coumarin and pyran derivatives in the presence of urotropine as inexpensive new tertiary amine with ionic liquids [BMIM] $\mathrm{BF}_{4}$ and [BIPIM]BF 4 in Baylis-Hillman reaction (Scheme 1 \& 2).<smiles>O=Cc1c(Cl)c2ccccc2oc1=O</smiles>
1<smiles>O=C1C=CCCC1</smiles>

2<smiles>[R]C(=O)C(=O)C(O)c1c(Cl)c2ccccc2oc1=O</smiles>

$3(\mathrm{a}-\mathrm{e})$

Scheme 1. Synthesis of Baylis-Hillman adducts (3a-e)<smiles>O=CBr</smiles>

4<smiles>O=c1ccocc1</smiles>

$\underset{\text { IL,Urotropine } / 140^{\circ} \mathrm{C}}{\text { IL,Urotropine/MW } 300 \mathrm{~W}}$

5<smiles>O=c1ccocc1C(O)Br</smiles>

6(a-g)

Scheme 2. Synthesis of Baylis-Hillman adducts (6a-g)

In a continuation of our research work for the synthesis of heterocylic compounds by using ionic liquids ${ }^{15}$, we employed two different ionic liquids based imidazolium tetrafluoroborate [BMIM]BF 4 and [BIPIM] $\mathrm{BF}_{4}$ as a green chemical solvents. The ILs plays the dual role of solvent and catalyst. The rapid use of microwave activation as a non conventional energy source in organic chemistry has also helped us in devising the present synthetic route.

With $p$-chlorobenzaldehyde and pyran as the standard components for the Baylis-Hillman reaction was selected as the model, a set of ionic liquids were screened to assess the rate enhahancing abilities of ionic liquids. The reaction was conducted in the presence of $5 \mathrm{~mol} \%$ of amine catalyst in [BMIM] $\mathrm{BF}_{4}$ at $140{ }^{\circ} \mathrm{C}$ obtained $68 \%$ in $3.0 \mathrm{~h}$. In these conditions [BIPIM] $\mathrm{BF}_{4}$ 
yielded $81 \%$ in $1.5 \mathrm{~h}$. But when we performed same reaction under microwave irradiation at $300 \mathrm{~W}$ with [BMIM]BF 4 afforded the product $\mathbf{6 a}$ in $75 \%$ yield within 4 min and [BIPIM] $\mathrm{BF}_{4}$ gave the product in $85 \%$ yield 3.5 min. (Table 1, entry 6). A synthetic strategy using [BIPIM] $\mathrm{BF}_{4}$ ionic liquid and microwave irradiation collectively was found to be a successful and efficient method for the synthesis of Baylis-Hillman adducts.

Table 1. Synthesis Baylis-Hillman adducts 3a-e and 6a-g in ionic liquid under conventional and microwave irradiation

\begin{tabular}{|c|c|c|c|c|c|c|c|}
\hline \multirow[b]{3}{*}{${ }_{\dot{m}}^{\circ}$} & \multirow[b]{3}{*}{ ArCHO } & \multicolumn{2}{|c|}{$[\mathrm{BMIM}] \mathrm{BF}_{4}$} & \multicolumn{3}{|c|}{$[\mathrm{BIPIM}] \mathrm{BF}_{4}$} & \multirow{3}{*}{$\begin{array}{c}\text { IL+ MW } \\
\text { Time, min/ } \\
\text { Yield, \% }\end{array}$} \\
\hline & & & & Only IL & $\mathrm{IL}+\mathrm{MW}$ & Only IL & \\
\hline & & $\mathrm{R}$ & Product & $\begin{array}{c}\text { Time, h/ } \\
\text { Yield, \% }\end{array}$ & $\begin{array}{c}\text { Time, min/ } \\
\text { Yield, \% }\end{array}$ & $\begin{array}{c}\text { Time, h/ } \\
\text { Yield, \% }\end{array}$ & \\
\hline 1 & & & 3a & $6 / 62$ & $4 / 66$ & $4 / 73$ & $3.5 / 76$ \\
\hline 2 & & & $3 b$ & $2.5 / 76$ & $3 / 79$ & $1.5 / 86$ & $3 / 83$ \\
\hline 3 & & & $3 c$ & $2 / 78$ & $2 / 82$ & $1 / 88$ & $2 / 84$ \\
\hline 4 & & & $3 d$ & $8 / 70$ & $4.5 / 74$ & $6 / 81$ & $4 / 84$ \\
\hline 5 & & & 3e & $3 / 71$ & $3 / 71$ & $2.5 / 82$ & $2 / 84$ \\
\hline 6 & & & $6 a$ & $3 / 68$ & $4 / 75$ & $1.5 / 81$ & $3.5 / 85$ \\
\hline 7 & & & $6 b$ & $6 / 62$ & $5 / 63$ & $5.5 / 82$ & $4.5 / 83$ \\
\hline 8 & & & $6 c$ & $9 / 50$ & $8 / 56$ & $7.5 / 80$ & $6.5 / 80$ \\
\hline 9 & & & 6d & $1 / 75$ & $2 / 80$ & $1 / 80$ & $1.5 / 86$ \\
\hline 10 & & & $6 e$ & $2 / 74$ & $2.5 / 79$ & $1 / 86$ & $2 / 82$ \\
\hline 11 & & & $6 f$ & $12 / 52$ & $9 / 58$ & 8/82 & 7/88 \\
\hline 12 & & & $6 g$ & $8 / 55$ & $6 / 56$ & 6/83 & 4/86 \\
\hline
\end{tabular}


The in vitro antibacterial activity of newly synthesized compounds 3a-e and $\mathbf{6 a - g}$ were determined by disc diffusion method ${ }^{16}$. The antibacterial screening revealed that some of the tested compounds showed good inhibition against various tested microbial strains. The results indicated that among the tested compounds, 3a and $\mathbf{6 a}$ showed excellent activity against Gram positive bacteria. Compounds $3 \mathbf{3 e}, \mathbf{6 b}, \mathbf{6 c}, \mathbf{6 e}, \mathbf{6 f}$ and $\mathbf{6 g}$ displayed moderate activity towards both gram positive and gram negative bacteria. On the other hand $\mathbf{3 b}, \mathbf{3 c}$, $\mathbf{3 d}$ and $\mathbf{6 d}$ exhibited least activity against both bacteria. Comparative docking of alpha amylase with the ligand molecules was done in correlation to in vitro antibacterial activity. The molecular docking of ligand molecules with glucosamine-6-phosphate revealed that the compound $\mathbf{3 a}$ has exhibited the interactions with the other amino acids in the active pockets which is showed in Figure 1.

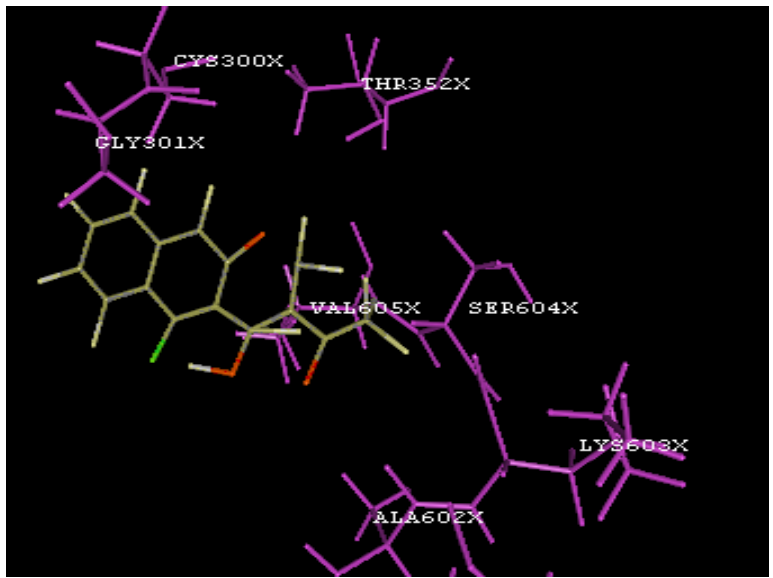

Figure 1. The best and stable conformations of 3a. (i) Forming $0 \mathrm{H}$ bond; (ii) bonding residues (4A): CYS300X, THR352X, GLY301X, VAL605X, SER604X, LYS603X and ALA602X

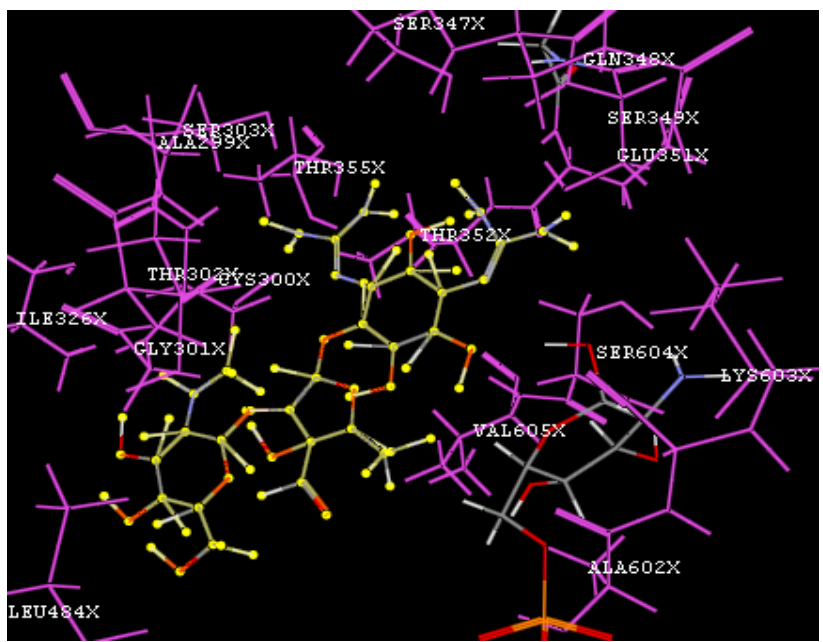

Figure 2. The best and stable conformations of Streptomycin (i) forming $3 \mathrm{H}$ bonds; (ii) bonding residues $\left(4 \mathrm{~A}^{0}\right)$ : SER347X, GLN348X, SER349X,GLU352X, SER303X, ALA299X, THR355X, THR302X, THR355X, GLY301X, ILE326X, VAL605X, ALA602X, LYS603X, SER604X, VAL605X, THR352X, CYS300X and ASP354X 
For docking calculations, Gasteigere-Marsili partial charges were assigned to the ligands and non-polar hydrogen atoms were merged. All torsions were allowed to rotate during docking. The systematic and Monte-Carlo methods were applied for minimization, using default parameters. Theoretically all the ligand molecules showed encouraging docking score. Among the synthesized molecules, docking of glucosamine-6-phosphate with 3a and 6a revealed that their docking scores were -4.757110 and $-4.982210 \mathrm{k} \cdot \mathrm{cal} \mathrm{mol}^{-1}$, respectively and it can be predicted as good inhibitor of glocosamine-6-phosphate compared to standard drug Streptomycin which has docking score -3.690558 k.cal mol ${ }^{-1}$.

\section{Antibacterial activity}

The anti-bacterial activity of newly synthesized compounds 3a-e and $\mathbf{6 a - g}$ was determined by agar disc-diffusion method. In the present study, B. subtilis (MTCC 121), Bacillus sp. (MTCC 10616), P. putida (MTCC 10617) and E. coli (MTCC 1652) were used as antibacterial strains and streptomycin was used as a standard antibacterial drug. Sterile filter paper discs (6 mm diameter) moistened with the test compound solution in DMSO of specific concentration $100 \mathrm{mg}$ and $200 \mathrm{mg} /$ disc were carefully placed on the agar culture plates that had been previously inoculated separately with the microorganisms. The plates were incubated at $37^{\circ} \mathrm{C}$ and the diameter of the growth inhibition zones were measured after $24 \mathrm{~h}$. The antibacterial results were compared with streptomycin and the results were summarized in Table 2.

Table 2. Zone of inhibition, $\mathrm{mm}$

\begin{tabular}{cccccc}
\hline \multirow{2}{*}{ Compound } & $\begin{array}{c}\text { Concentration, } \\
\mu \mathrm{g} / \mathrm{mL}\end{array}$ & \multicolumn{2}{c}{ Gram-positive } & \multicolumn{2}{c}{ Gram-negative } \\
& 100 & 29 & 27 & 20 & 20 \\
\hline \multirow{2}{*}{ 3a } & 200 & 33 & 31 & 24 & 23 \\
& 100 & 12 & 12 & 12 & 14 \\
3b & 200 & 15 & 13 & 15 & 17 \\
& 100 & 15 & 15 & 14 & 12 \\
3c & 200 & 18 & 17 & 16 & 15 \\
& 100 & 15 & 16 & 14 & 16 \\
3d & 200 & 18 & 17 & 17 & 19 \\
& 100 & 19 & 17 & 16 & 18 \\
3e & 200 & 21 & 19 & 18 & 20 \\
& 100 & 32 & 37 & 33 & 31 \\
6a & 200 & 37 & 39 & 36 & 34 \\
& 100 & 20 & 18 & 16 & 16 \\
6b & 200 & 23 & 23 & 18 & 19 \\
& 100 & 21 & 19 & 16 & 19 \\
6c & 200 & 23 & 23 & 19 & 21 \\
& 100 & 16 & 14 & 15 & 16 \\
6d & 200 & 18 & 17 & 18 & 18 \\
& 100 & 17 & 19 & 17 & 16 \\
6e & 200 & 20 & 22 & 20 & 18 \\
& 100 & 19 & 17 & 17 & 18 \\
6f & 200 & 23 & 20 & 19 & 21 \\
& 100 & 19 & 16 & 18 & 19 \\
6g & 200 & 23 & 18 & 20 & 20 \\
\multirow{2}{*}{ Streptomycin } & 100 & 35 & 38 & 37 & 42 \\
& 200 & 41 & 44 & 42 & 45 \\
\hline
\end{tabular}




\section{Molecular docking studies}

\section{Ligand preparation}

The structure of Balis-Hilmann adducts of chromen and pyran derivatives were used as the template to build the molecules in the dataset in VLife MDS 3.5. The ligand geometries were optimized by energy minimization using MMFF94 force field and Gasteiger-Marsili charges for the atoms, till a gradient of $0.001 \mathrm{kcal} / \mathrm{mol} / \mathrm{A}^{\circ}$ was reached, maintaining the template structure rigid during the minimization.

\section{Preparation of the grid file}

The grid map was centered at the active pocket of the protein by VLife MDS 3.5 (Figure 1). The grid map, which was centered at the following residues of the protein Ser 349 (X), Gln 348 (X), Ser 303(X), Thr 302(X), Val 399 (X), Ala 602 (X), Thr 352(X), Ser 347 (X) which were predicted from the ligplot.

\section{Preparation of the docking file}

Over activation of receptor glucosamine-6-phosphate synthase from Escherichia coli complexed with glucosamine-6-phosphate (2VF5) signaling pathways is strongly associated with antibacterial activity. On this basis, we selected 2VF5 as a biological target for docking study of synthesized compounds. The crystal structure of 2VF5 was obtained from the protein Data Bank (www.rcsb.org/pdb). The optimized receptor was then saved as mol file and used for docking simulation. The 2D structure of the compounds were built and then converted into the 3D with the help of VLife MDS 3.5 software. The 3D structures were then energetically minimized up to the rms gradient of 0.01 using Merck Molecular Force Field (MMFF). Conformers of all the synthesized ligands were selected and were then energetically minimized up to the rms gradient of 0.01 and then saved in separate folder. The active site selection was done by choosing the cavity having maximum hydrophobic surface area. Docking simulation was done by GA docking method. All the conformers were virtually docked at the defined cavity of the receptor. The parameters fixed for docking simulation was like this number of placements: 30, rotation angle: $30^{\circ}$, exhaustive method, scoring function: dock score. By rotation angle, the ligand gets rotated for different poses. By placements, the method will check all the 30 possible placements into the active site pocket and results out few best placements out of 30. For each ligand, all the conformers with their best placements and their dock score will be saved in output folder. The method also highlights the best placement of best conformer of one particular ligand which is having best (minimum) dock score. In the results of docking, we have listed only best conformers and its dock score for each ligand. After docking simulation, the best docked conformer of each ligand and receptor were merged and aggregated by defining the radius of $4 \AA$. The receptor complexes were then energetically minimized along with the docked ligand. Stepwise aggregation was done first with hydrogen, second side chains and finally the backbone of receptor ${ }^{17}$. The optimized complexes were then checked for various interaction of ligand with receptor like hydrogen bonding, hydrophobic bonding and Vander Waal's interaction.

\section{General procedure for baylis-hillman reaction in ionic liquid}

Procedure with only ionic liquid

To a mixture of aldehyde $(0.5 \mathrm{mmol})$ and alkene $(0.5 \mathrm{mmol})$ in ionic liquid $(1 \mathrm{~mL})$, urotropine (0.5 mmole) was added. The reaction mixture was stirred at $140{ }^{\circ} \mathrm{C}$ for appropriate time (Table 1). After completion of the reaction (monitored by TLC), the reaction mixture was diluted with $10 \mathrm{~mL}$ of water and extracted with dichloromethane (4x5 mL) and 
the combined fractions were dried and evaporated under reducer pressure. The crude product was purified by column chromatography on a silica gel (EA:Pet.Ether: 5/95) to get the pure products 3a-e and 6a-g.

\section{Procedure for using ionic liquid and microwave heating}

A mixture of aldehyde $(0.5 \mathrm{mmol})$ and alkene $(0.5 \mathrm{mmol})$ in ionic liquid $(1 \mathrm{~mL})$, urotropine ( 0.5 mmole) was added. The reaction mixture was mixed well and then irradiated in a micro oven at 300 Watts for appropriate time (Table 1). After completion of the reaction (monitored by TLC), the reaction mixture was diluted with $10 \mathrm{~mL}$ of water and extracted with dichloromethane $(4 \times 5 \mathrm{~mL})$ and the combined fractions were dried and evaporated under reducer pressure. The crude product was purified by column chromatography on a silica gel (EA:Pet.Ether: 5/95) to get the pure products 3a-e and 6a-g.

\section{4-Chloro-3-(1-hydroxy-2-methylene-3-oxo-butyl)-chromen-2-one (3a)}

Yellow solid; mp: $162-164{ }^{\circ} \mathrm{C}$; IR $\left(\mathrm{KBr}, \mathrm{cm}^{-1}\right)$ : 3423, 1723 and $1655 ;{ }^{1} \mathrm{H}$ NMR $\left(\mathrm{CDCl}_{3}, 300\right.$ MHz): $\delta 2.34\left(3 \mathrm{H}, \mathrm{s}, \mathrm{CH}_{3}\right), 4.57(1 \mathrm{H}$, br s, $\mathrm{OH}), 5.59(1 \mathrm{H}, \mathrm{s}, \mathrm{C}-\mathrm{H}), 6.14$ and $6.43(2 \mathrm{H}, 2 \mathrm{xs}$, $\left.\mathrm{CH}_{2}\right)$, 7.21-7.33 (2H, m, Ar-H), 7.40-7.49 (2H, m, Ar-H); ${ }^{13} \mathrm{C}$ NMR $\left(\mathrm{CDCl}_{3}, 75 \mathrm{MHz}\right): \delta$ 26.0, 67.6,119.3, 122.3, 124.0, 125.4, 126.1,127.4, 133.0, 143.0, 151.5, 152.3, 168.3, 190.5; MS: $279(\mathrm{M}+1)$; Anal. Calcd for $\mathrm{C}_{14} \mathrm{H}_{11} \mathrm{ClO}_{4}$ : C, 60.34; H, 3.98. Found: C, 60.24; $\mathrm{H}, 3.87 \%$.

\section{2-[(4-Chloro-2-oxo-2H-chromen-3-yl)-hydroxy-methyl]-acrylamide (3b)}

Yellow solid; mp: $158-160{ }^{\circ} \mathrm{C}$; IR $\left(\mathrm{KBr}, \mathrm{cm}^{-1}\right): 3418,3329,1726$ and $1629 ;{ }^{1} \mathrm{H}$ NMR $\left(\mathrm{CDCl}_{3}, 300 \mathrm{MHz}\right): \delta 4.47\left(1 \mathrm{H}\right.$, br s, OH), $5.69(1 \mathrm{H}, \mathrm{s}, \mathrm{C}-\mathrm{H}), 6.10$ and $6.43\left(2 \mathrm{H}, 2 \mathrm{xs}, \mathrm{CH}_{2}\right)$, 7.18-7.23 (2H, m, Ar-H), 7.36-7.44 (2H, m, Ar-H). MS: $280(\mathrm{M}+1)$; Anal. Calcd for $\mathrm{C}_{13} \mathrm{H}_{10} \mathrm{ClNO}_{4}$ : C, 55.83; H, 3.60, N,5.01;. Found: C, 55.80; H, 3.62, N,3.08\%.

\section{3-[(4-Chloro-2-oxo-2H-chromen-3-yl)-hydroxy-methyl]-2-oxo-but-3-enenitrile (3c)}

Yellow solid; mp: $170-172{ }^{\circ} \mathrm{C}$; IR $\left(\mathrm{KBr}, \mathrm{cm}^{-1}\right)$ : 3400, 1726, 1658 and 2240; ${ }^{1} \mathrm{H}$ NMR $\left(\mathrm{CDCl}_{3}, 300 \mathrm{MHz}\right): \delta 4.40\left(1 \mathrm{H}\right.$, br s, OH), $5.55(1 \mathrm{H}, \mathrm{s}, \mathrm{C}-\mathrm{H}), 6.11$ and $6.41\left(2 \mathrm{H}, 2 \mathrm{xs}, \mathrm{CH}_{2}\right)$, 7.19-7.27 (2H, m, Ar-H), 7.38-7.42 (2H, m, Ar-H); MS: $290(\mathrm{M}+1)$. Anal. Calcd for $\mathrm{C}_{14} \mathrm{H}_{8} \mathrm{ClNO}_{4}$ : C, 58.05; H, 2.78, N,4.84. Found: C, 58.15; H, 2.62, N,4.79\%.

2-[(4-Chloro-2-oxo-2H-chromen-3-yl)-hydroxy-methyl]-acrylic acid ethyl ester (3d) Yellow solid; mp: $180-182{ }^{\circ} \mathrm{C}$; IR $\left(\mathrm{KBr}, \mathrm{cm}^{-1}\right)$ : 3408, 1718 and $1645 ;{ }^{1} \mathrm{H}$ NMR $\left(\mathrm{CDCl}_{3}, 300\right.$ MHz): $\delta 1.28\left(3 \mathrm{H}, \mathrm{t}, \mathrm{CH}_{3}\right), 4.10\left(2 \mathrm{H}, \mathrm{q}, \mathrm{CH}_{2}\right), 4.56(1 \mathrm{H}, \mathrm{br} \mathrm{s}, \mathrm{OH}), 5.54(1 \mathrm{H}, \mathrm{s}, \mathrm{C}-\mathrm{H}), 6.13$ and $6.45\left(2 \mathrm{H}, 2 \mathrm{xs}, \mathrm{CH}_{2}\right), 7.24-7.33(2 \mathrm{H}, \mathrm{m}, \mathrm{Ar}-\mathrm{H}), 7.41-7.49(2 \mathrm{H}, \mathrm{m}, \mathrm{Ar}-\mathrm{H})$; MS: 309 $(\mathrm{M}+1)$. Anal. Calcd for $\mathrm{C}_{15} \mathrm{H}_{13} \mathrm{ClO}_{5}$ : C, 58.36; H, 4.24. Found: C, 58.24; H, 4.17\%.

\section{4-Chloro-3-[hydroxy-(6-oxo-cyclohex-1-enyl)-methyl]-chromen-2-one (3e)}

Yellow solid; mp: $138-140{ }^{\circ} \mathrm{C}$; IR $\left(\mathrm{KBr}, \mathrm{cm}^{-1}\right)$ : 3408, 1740 and $1655 ;{ }^{1} \mathrm{H}$ NMR $\left(\mathrm{CDCl}_{3}, 300\right.$ MHz): $\delta$ 1.97-2.05 (m, 2H), 2.37-2.50 (m, 4H), $4.53(1 \mathrm{H}, \mathrm{br} \mathrm{s}, \mathrm{OH}), 5.32(1 \mathrm{H}, \mathrm{s}, \mathrm{C}-\mathrm{H}), 5.88$ (t, 1H), 7.06-7.13 (m, 2H); 7.26-7.33 (m, 2H); MS: $305(\mathrm{M}+1)$. Anal. Calcd for $\mathrm{C}_{16} \mathrm{H}_{13} \mathrm{ClO}_{4}$ : C, 63.06; H, 4.30. Found: C, 63.03; H, 4.19\%.

\section{3-[(4-Chlorophenyl)hydroxymethyl]-4H-pyran-4-one (6a)}

Oily compound; IR $\left(\mathrm{KBr}, \mathrm{cm}^{-1}\right)$ : 3355, 1654; ${ }^{1} \mathrm{H}$ NMR $\left(\mathrm{CDCl}_{3}, 300 \mathrm{MHz}\right): \delta 4.28(1 \mathrm{H}, \mathrm{br} \mathrm{s}$, $\mathrm{OH}), 5.71(1 \mathrm{H}, \mathrm{s}), 6.32(1 \mathrm{H}, \mathrm{d}), 7.28-7.37(4 \mathrm{H}, \mathrm{m}), 7.45(1 \mathrm{H}, \mathrm{s}), 7.77(1 \mathrm{H}, \mathrm{d}) ;{ }^{13} \mathrm{C} \mathrm{NMR}$ $\left(\mathrm{CDCl}_{3}, 75 \mathrm{MHz}\right): \delta$ 69.8, 117.1, 127.6, 128.6, 131.5, 133.5, 138.6, 153.4, 155.7, 178.6; MS: $237(\mathrm{M}+1)$. Anal. Calcd for $\mathrm{C}_{12} \mathrm{H}_{9} \mathrm{ClO}_{3}$ : C, 60.90; H, 3.83. Found: C, 60.86; H, 3.80\%. 


\section{3-(Hydroxyphenylmethyl)-4H-pyran-4-one (6b)}

Pale yellow semi solid; IR $\left(\mathrm{KBr}, \mathrm{cm}^{-1}\right)$ : 3384, 1650; ${ }^{1} \mathrm{H}$ NMR $\left(\mathrm{CDCl}_{3}, 300 \mathrm{MHz}\right): \delta 4.55$ (1H, br s, OH), $5.69(1 \mathrm{H}, \mathrm{s}), 6.55(1 \mathrm{H}, \mathrm{d}), 7.30-7.41(5 \mathrm{H}, \mathrm{m}), 7.48(1 \mathrm{H}, \mathrm{s}), 7.69(1 \mathrm{H}, \mathrm{d}) ;{ }^{13} \mathrm{C}$ NMR $\left(\mathrm{CDCl}_{3}, 75 \mathrm{MHz}\right): \delta$ 69.8, 116.9, 125.8, 128.6, 128.9, 131.8, 140.3, 152.9, 155.8, 178.7; MS: 203 (M+1). Anal. Calcd for $\mathrm{C}_{12} \mathrm{H}_{10} \mathrm{O}_{3}$ : C, 71.28; H, 4.98. Found: C, 70.21; $\mathrm{H}$, 4.87 .

\section{3-(Hydroxy-4-tolylmethyl)-4H-pyran-4-one (6c)}

Pale Yellow semi solid; IR (KBr, $\left.\mathrm{cm}^{-1}\right)$ : 3406, 1655; ${ }^{1} \mathrm{H}$ NMR $\left(\mathrm{CDCl}_{3}, 300 \mathrm{MHz}\right): \delta 2.34$ (3H, s), $4.31(1 \mathrm{H}$, br s, OH), $5.74(1 \mathrm{H}, \mathrm{s}), 6.39(1 \mathrm{H}, \mathrm{d}), 7.19(2 \mathrm{H}, \mathrm{d}), 7.36(2 \mathrm{H}, \mathrm{m}), 7.46-7.78$ $(2 \mathrm{H}, \mathrm{m}) ;{ }^{13} \mathrm{C}$ NMR $\left(\mathrm{CDCl}_{3}, 75 \mathrm{MHz}\right): \delta 22.1,70.1,118.2,126.2,129.1,132.1,135.0,137.8$, 152.5, 155.9, 177.8; MS: $217(\mathrm{M}+1)$. Anal. Calcd for $\mathrm{C}_{13} \mathrm{H}_{12} \mathrm{O}_{3}$ : C, 72.21; H, 5.59; Found: $\mathrm{C}$, 72.10; H, 5.57\%.

\section{3-[Hydroxy(4-nitrophenyl)methyl]-4H-pyran-4-one (6d)}

Yellow solid; mp: $162-164{ }^{\circ} \mathrm{C}$; IR $\left(\mathrm{KBr}, \mathrm{cm}^{-1}\right): 3400,1645 ;{ }^{1} \mathrm{H}$ NMR $\left(\mathrm{CDCl}_{3}, 300 \mathrm{MHz}\right): \delta$ $4.25(1 \mathrm{H}$, br s, OH), $5.82(1 \mathrm{H}, \mathrm{s}), 6.22(\mathrm{~s}, 1 \mathrm{H}), 7.65(2 \mathrm{H}, \mathrm{d}), 7.81(1 \mathrm{H}, \mathrm{d}), 7.86(1 \mathrm{H}, \mathrm{d}), 8.16$ (2H, d); ${ }^{13} \mathrm{C} \mathrm{NMR}\left(\mathrm{CDCl}_{3}, 75 \mathrm{MHz}\right): \delta 67.5,117.1,122.9,127.9,131.9,146.5,151.2,154.6$, 157.2, 176.3. MS: $248(\mathrm{M}+1)$. Anal. Calcd for $\mathrm{C}_{12} \mathrm{H}_{9} \mathrm{NO}_{5}$ : C, 58.30; $\mathrm{H}, 3.67, \mathrm{~N}, 5.67$. Found: C, 58.21; H, 3.67, N, .5.63\%.

\section{3-[Hydroxy(4-nitrophenyl)methyl]-4H-chromen-4- one (6e)}

Pale Yellow solid; mp:186-187 ${ }^{\circ} \mathrm{C}$; IR $\left(\mathrm{KBr}, \mathrm{cm}^{-1}\right)$ : 3395, 1629; ${ }^{1} \mathrm{H}$ NMR $\left(\mathrm{CDCl}_{3}\right) 300$ MHz): $\delta 5.84(1 \mathrm{H}, \mathrm{s}), 6.22(1 \mathrm{H}, \mathrm{d}), 7.42(1 \mathrm{H}, \mathrm{t}), 7.60(1 \mathrm{H}),, 7.70(2 \mathrm{H}, \mathrm{d}), 7.75(1 \mathrm{H}), 7.98$ $(1 \mathrm{H}, \mathrm{d}), 8.11(2 \mathrm{H}, \mathrm{d}), 8.41(1 \mathrm{H}, \mathrm{s}) ;{ }^{13} \mathrm{C} \mathrm{NMR}\left(\mathrm{CDCl}_{3}, 75 \mathrm{MHz}\right): \delta 66.7,118.4,123.2,124.8$, 125.5, 126.2, 127.6, 134.3, 134.2, 146.4, 151.1, 154.4, 155.7, 175.1; Anal. Calcd for $\mathrm{C}_{16} \mathrm{H}_{11} \mathrm{NO}_{5}$ Found : C, 64.67; H, 3.74; Calculated: C, 64.65; H, 3.73; MS: $298(\mathrm{M}+1)$.

\section{3-(Hydroxy(4-methoxyphenyl)methyl)-4H-pyran-4-one (6f)}

Yellow solid; mp: $186-187{ }^{\circ} \mathrm{C}$; IR (KBr, $\left.\mathrm{cm}^{-1}\right)$ : 3404, 1647; ${ }^{1} \mathrm{H}$ NMR $\left(\mathrm{CDCl}_{3}, 300 \mathrm{MHz}\right): \delta$ $3.84(3 \mathrm{H}, \mathrm{s}), 4.28$ (1H, br s), $5.74(1 \mathrm{H}, \mathrm{s}), 6.34(1 \mathrm{H}, \mathrm{d}), 7.15(2 \mathrm{H}, \mathrm{d}), 7.30(2 \mathrm{H}, \mathrm{d}), 7.46(1 \mathrm{H}, \mathrm{s})$, 7.71(1H, d); ${ }^{13} \mathrm{C} \mathrm{NMR}\left(\mathrm{CDCl}_{3}, 75 \mathrm{MHz}\right): \delta$ 62.0, 70.1, 117.6, 126.9, 129.4, 132.6, 137.1, 138.1, 153.6, 155.7, 178.9; MS: 233 (M+1) Anal. Calcd for $\mathrm{C}_{13} \mathrm{H}_{12} \mathrm{O}_{4}$ : C, 67.23; H, 5.21. Found: C, 67.21; H, 5.27\%.

\section{3-[Hydroxy(4-Methylphenyl)methyl]-4H-chromen-4- one (6g)}

Pale Yellow semi solid; IR ( $\left.\mathrm{KBr}, \mathrm{cm}^{-1}\right)$ : 3390, 1627; ${ }^{1} \mathrm{H}$ NMR $\left(\mathrm{CDCl}_{3}, 300 \mathrm{MHz}\right): \delta 2.33$ $(3 \mathrm{H}, \mathrm{s}), 5.87(1 \mathrm{H}, \mathrm{s}), 6.23(1 \mathrm{H}, \mathrm{d}), 7.44(1 \mathrm{H}, \mathrm{t}), 7.62(1 \mathrm{H}, \mathrm{d}), 7.72(2 \mathrm{H}, \mathrm{d}), 7.76(1 \mathrm{H}), 7.98$ $(1 \mathrm{H}, \mathrm{d}), 8.11(2 \mathrm{H}, \mathrm{d}), 8.42(1 \mathrm{H}, \mathrm{s}) ;{ }^{13} \mathrm{C} \mathrm{NMR}\left(\mathrm{CDCl}_{3}, 75 \mathrm{MHz}\right): \delta 25.1,67.1,118.5,123.6$, 125.4, 125.9, 126.7, 128.1, 134.2, 134.6, 146.9, 151.7, 154.6, 156.2,175.3; Anal. Calcd: $\mathrm{C}_{17} \mathrm{H}_{14} \mathrm{O}_{3}$; Found: C, 76.70; H, 5.37; Calculated : C, 76.68; H, 5.30; MS:267 (M+1).

\section{Conclusion}

Coumarin and pyran derivatives (Baylis-Hilmann adducts) were synthesized and characterized by analytical IR, ${ }^{1} \mathrm{H}$ NMR and mass spectral studies. All the compounds were screened for their antibacterial properties and also studied their molecular docking. The synthesized molecules seem to be useful as specific antibacterial agents against specific bacteria. Further evaluation is necessary for their clinical use. 


\section{Acknowledgement}

The authors are thankful to the Director, NIT, Warangal for providing facilities and financial support.

\section{References}

1. (a) El-saghier A M and Khodiyar A, Phosphorus, Sulfur and Silicon, 2000, 160, 105; (b) Musicki B, Periers A M, Laurin P, Ferroud D, Bendetti Y, Lachaud S, Chatreaux F, Haesslein J L, lltis A, Pierre C, Khider J, Tessot N, Airault P, Bonnefoy P, Vicat P and Klich M, Bioorg Med Chem Lett., 2000, 10(15), 1695-1699.

2. (a) Azizian J, Mohammadi A, Bidar I and Mirazaei P, Montash Chem., 2008, 139, 805; (b) Satyanarayan V S, Sreevani P, Sivakumar A and Vijay Kumar, Arkivoc, 2008, 17, 221.

3. (a) Garazd M M, Muzychka O V, Voyk A I, Nagorichna I V and Ogorodniichuk A S, Chem Nat Compd., 2007, 43, 19.

4. (a) Smitha G and Sanjeeva R, Synth Commun., 2004, 34, 3997; (b) Kotali A, Lafazanis I and Harris P, Synth Commun., 2008, 38, 3996-4006; (c) Hamdi N, Lidrissi C, Saoud M, Nievas A R and Zarrouk H, Chem Heterocycl Compd., 2006, 42(3), 320-325.

5. Maheswara M, Siddaiah V, Damu G L, Rao Y K and Rao C V, J Mol Catal A: Chem., 2006, 255, 49; (b) Rajitha B, Kumar V N, Someshwar P, Madhav J V, Reddy P N and Reddy Y T, Arkivoc, 2006, 12, 23.

6. (a) Zahradnik M, The production and application of fluorescent brightening agents: Wiley: New York, 1992; (b) Sizova Z A, Karasev A A, Lukatskaya L L, Rubtsov M I and Doroshenko A O, Theor Exp Chem., 2002, 38, 168.

7. (a) Uher M, Konecny V and Rajniakova O, Chem Pap., 1994, 48(4), 282; (b) PerezPerez M, Balzarini J, Rozenski J, De-Clercq E and Herdewijn P, Bioorg Med Chem Lett., 1995, 5, 1115-1118.

8. $\quad$ Aytemir M D, Calis U and Ozalp M, Arch Pharm., 2004, 337, 281.

9. (a) Schreiber S L, Science, 2000, 287, 1964; (b) Burke M D, Berger E M and Schreiber S L, Science, 2003, 302, 613-618.

10. Basavaiah D, Rao A J and Satyanarayana T, Chem Rev., 2003, 103, 811.

11. Singh V and Batra S, Tetrahedron, 2008, 64, 4511.

12. Blazevic N, Kolbah D, Belin B, Sunjic V and Kajfez F, Synthesis, 1979, 161-176.

13. Bhattacharya A, Segmuller B and Ybarra A, Synth Commun., 1996, 26, 1775-1784.

14. Cai J, Zhou Z, Zhao G and Tang C, Org Lett., 2002, 4, 4723-4725.

15. (a) Kanakaraju S, Prasanna B, Basavoju S and Chandramouli G V P, J Mol Struct., 2012, 1017, 60; (b) Kanakaraju S, Prasanna B and Chandramouli G V P, J Chem., 2013, Article ID 104690, 1.

16. Pimentel L C F, de Souza A L F, Fernandez T L, Wardell J L and Antunes O A C, Tetrahedron Lett., 2007, 48, 831-833.

17. National Committee for Clinical Laboratory Standards (NCCLS), Approved Standard Document M7-A3, Villanova, PA, 1993. 